\title{
MAŁŻONKOWIE W SLUŻBIE EWANGELIZACJI W PIERWOTNYM KOŚCIELE
}

Działalność misyjna pierwotnego Kościoła ukazana została przede wszystkim $w$ Dziejach Apostolskich $i$ w listach świętego Pawła. Prowadzili ja nie tylko apostołowie, misjonarze czy wędrowni nauczyciele, ale aktywnie właczaty się w nia także pary matżeńskie. Wymienić należy najpierw tu matżeństwa apostołów, pary matżeńskie wymienione w Rz 16 i Flm, a przede wszystkim Akwile i Pryscylle, którzy całe swoje życie poświęcili stużbie Ewangelii.

Słowa kluczowe: matżeństwo, ewangelizacja, apostot, pierwotny Kościót, Pawet, Akwila, Pryscylla.

W niniejszym artykule nakreślimy obraz działalności misyjnej pierwotnego Kościoła na podstawie relacji Dziejów Apostolskich i listów św. Pawła. Działalność tę prowadzili nie tylko apostołowie i misjonarze, ale włączało się w nią - w różnym stopniu i na różne sposoby - wiele osób, a wśród nich chrześcijańscy małżonkowie. Obok małżeństw apostołów (1 Kor 9,5) i par małżeńskich wymienionych w Rz 16 i w Flm 1-3 najbardziej znane jest małżeństwo Akwili i Pryscylli, któremu poświęcimy najwięcej uwagi.

\section{Gloszenie Ewangelii w pierwotnym Kościele}

Gdy mówimy o życiu pierwotnego Kościoła, to od razu przychodzi na myśl księga Dziejów Apostolskich, która prezentuje Kościół w perspektywie jego

* Ks. prof. UKSW dr hab. Andrzej Jacek Najda - kapłan diecezji łomżyńskiej, dr hab. w zakresie teologii biblijnej, prof. Uniwersytetu Kardynała Stefana Wyszyńskiego w Warszawie, pracownik naukowy i członek Rady Wydziału Studiów nad Rodziną UKSW, kierownik Katedry Teologii Systematycznej Małżeństwa i Rodziny, redaktor naczelny „Studiów nad Rodziną”, wykładowca Wyższego Seminarium Duchownego w Łomży. 
działalności ewangelizacyjnej. Stanowi ona kontynuację zapowiedzianego przez proroków zbawczego planu Boga i realizację danego apostołom przez Chrystusa nakazu misyjnego: „będziecie moimi świadkami w Jeruzalem i w całej Judei, i w Samarii, i aż po krańce ziemi” (Dz 1,8). Świadkowie prowadzą dalej to, „,co zaczął Jezus czynić i nauczać" (Dz 1,1), głosząc Ewangelię wszystkim narodom, począwszy od Jerozolimy. Właściwie całą opisaną w księdze działalność Kościoła nazwać można głoszeniem Ewangelii ${ }^{1}$.

Według relacji Dziejów Apostolskich w dzieło ewangelizacji włącza się i aktywnie angażuje cały Kościół ${ }^{2}$ i to już od dnia Zesłania Ducha Świętego, to jest od inauguracji swojej publicznej działalności. Napełnieni Duchem Świętym chrześcijanie, mężczyźni i kobiety, w liczbie „około stu dwudziestu osób” $(1,15)$ wysławiają wówczas „wielkie dzieła Boże” $(2,11)$. Wychodzą na ulice i place miasta i przemawiają w obcych językach do Żydów, przybyłych z różnych krajów do Jerozolimy na dzień Pięćdziesiątnicy (2,9-11). Możemy zakładać, że były wśród nich także małżeństwa. W dalszej części księgi czytamy o konkretnych osobach, które poświęcają się głoszeniu Chrystusa: apostołach (4,33; 5,42; 8,25), Piotrze, Pawle, Barnabie, Szczepanie, Filipie, Jakubie, Apollosie i o małżonkach Pryscylli i Akwili. Na dalszym planie widzimy również takie postacie epizodyczne, jak np. Sylas i Tymoteusz czy „około dwunastu mężczyzn” (19,7) z Efezu, którzy po otrzymaniu daru Ducha Świętego mówią językami i prorokują. Wszyscy ewangelizatorzy dają jednocześnie świadectwo o Chrystusie $(1,8 ; 10,42 ; 28,23)$, to znaczy publicznie wyznają wiarę w Niego nawet w obliczu prześladowań, cierpień i niebezpieczeństwa utraty życia $(7,56-60)^{3}$.

Dzieło ewangelizacji, na co wskazują Dzieje Apostolskie, to nie tylko głoszenie, ale także inne formy działalności. Wymienić można tu chociażby troskę o bezpieczeństwo misjonarzy i okazywaną im pomoc. I tak np. dostrzegając grożące Pawłowi zagrożenie, chrześcijanie z Damaszku nocą spuszczają go w koszu na sznurze przez mur miasta i wyprawiają do Jerozolimy $(9,25)$. Podobnie przychodzą Pawłowi z pomocą i wsparciem wierni z Jerozolimy $(9,30)$, Listry $(14,20)$, Tesaloniki (17,10), Berei $(17,14 n)$ i Cezarei Nadmorskiej $(21,16)$. Inni chrześcijanie

1 Ewangelię i Dzieje Apostolskie - obie części swego podwójnego dzieła - charakteryzuje Łukasz jako ewangelizowanie, a dokładniej jako ,przepowiadanie w formie przedstawienia historycznego", tak H. Zimmermann, Neutestamentliche Methodenlehre. Darstellung der historisch-kritischen Methode, neubearb. von K. Kliesch, Stuttgart ${ }^{7} 1982$, s. 143.

2 Por. S. Haręzga, Eklezjologia, w: Teologia Nowego Testamentu. Tom I. Ewangelie synoptyczne i Dzieje Apostolskie, red. M. Rosik, Wrocław 2008, s, 207.

3 Por. S. Haręzga, Eklezjologia, dz. cyt., s. 208. 
natomiast, jak np. Lidia (16,15), Jazon (17,5), Pryscylla i Akwila (18,3n), Tycjusz Justus $(18,7)$ czy Mnason z Cypru $(21,16)$, przyjmują pod swój dach misjonarzy i udzielają im gościny.

Warto zauważyć, że według Dziejów Apostolskich głoszenie Ewangelii nie dokonuje się jedynie w miejscach sakralnych ani tylko w religijnych okolicznościach. Co prawda Paweł najczęściej udaje się do synagog, w których przemawia do Żydów, apostołowie nauczają w świątyni $(5,20 \mathrm{n})$, a Piotr i Jan ewangelizują w krużganku Salomonowym $(3,11)$. Wielką rolę odgrywają również miejsca i przestrzenie związane z przestrzenią świecką i rodzinną. To przede wszystkim prywatne domy i mieszkania, jak np. Korneliusza (10,24-48), strażnika więzienia z Filippi (16,30-32) czy nieznanych z imienia osób z Jerozolimy (5,42), Troady (20,7-12) i Rzymu (28,16-31), czy takie miejsca publiczne, jak: miejsce modlitwy nad rzeką w Filippi $(16,13)$, ateński Areopag (17,19-31) i schody do twierdzy Antonia $(21,40-$ 22,21). Głoszenie Ewangelii dokonuje się również w drodze, w wozie wracającego z Jerozolimy Etiopa (8,26-36), a także w niecodziennych sytuacjach, takich jak: prześladowanie i uwięzienie. Mimo pozbawienia wolności odważnie świadczą o Chrystusie i nauczają Piotr i Jan (4,5.7), apostołowie (5,27-32) i Paweł (22,1-21; 24,24n; 26,1-23).

Jeżeli chodzi o treści ewangelizowania, to na pierwszy plan należy wysunąć „kazania misyjne” Piotra (2,14-39; 3,12-26; 4,8-12.19n; 5,29-32; 10,34-43) i Pawła (13,16-41; 14,15-17; 17,22-31). Oprócz tego czytamy, że apostołowie, Paweł i inni misjonarze głoszą: „,słowo Boże” $(4,31 ; 13,5 ; 18,11)$, „słowo” $(8,4 ; 11,19)$, „słowo Pańskie” (15,35.36), „Ewangelię” (8,25.40; 14,7.21; 16,10), „Jezusa” (17,3), „Chrystusa” (8,5), ,imię Jezusa” (4,17n; 5,28.40; 9,27n), „Jezusa i zmartwychwstanie” (17,18), „Dobrą Nowinę” $(8,35 ; 13,32)$, „to, co przepowiedzieli Prorocy i Mojżesz” (26,22), ,całą wolę Bożą" (20,27), „drogę” (16,17; 18,26; 19,23; 22,4; $24,22)^{4}$ i „,królestwo Boże” $(8,12 ; 14,22 ; 19,8 ; 20,25 ; 28,23.31)^{5}$. Chcąc bliżej, jednym pojęciem, określić treść nauczania pierwotnego Kościoła, należałoby z pewnością wskazać na królestwo Boże $e^{6}$.

4 Terminem o`do,j (= ,droga“) oznacza Łukasz w Dziejach Apostolskich zarówno naukę chrześcijańską $(13,10 ; 16,17 ; 18,25 n ; 19,9.23 ; 22,4 ; 24,22)$, jak również samo chrześcijaństwo $(9,2 ; 24,14)$. Por. W. Michaelis, Art. o’do,j ktl., w: ThWNT V, s. 93-95.

5 Por. H. Langkammer, Kerygmat paschalny w ewangeliach i Dziejach Apostolskich, Radom 2010, s. 57-97, 137-145.

6 Por. R. Schnackenburg, Gottes Herrschaft und Reich. Eine biblisch-theologische Studie, Freiburg 1959, s. 181-198; M. Wolter, »Reich Gottes« bei Lukas, „New Testament Studies“ 1995, R. 41, s. 541-563, 551n. S. Haręzga, Eklezjologia, dz. cyt., 208, stwierdza, że zarówno w czasie Jezusa, jak i w czasie Kościoła, „sercem ewangelizacji pozostaje 
Niejako drugim źródłem poznania działalności ewangelizacyjnej pierwotnego Kościoła są listy św. Pawła. Obok wykładu prawd wiary chrześcijańskiej i wskazań o charakterze parenetycznym apostoł mówi w nich również o sobie, o swoim życiu i pełnionej posłudze. Cztery razy wspomina o wydarzeniu pod Damaszkiem (Ga 1,15-16; 1 Kor 9,1; 15,8; 2 Kor 4,6) $)^{7}$, które było dla niego nie tylko nawróceniem, lecz przede wszystkim objawieniem Zmartwychwstałego Jezusa, który Go wybrał, powołał i posłał, aby głosił Ewangelię narodom pogańskim ${ }^{8}$. Paweł z gorliwego faryzeusza i prześladowcy chrześcijan (por. Ga 1,13-14) stał się „apostołem Chrystusa Jezusa", co wielokrotnie podkreśla w swoich listach (Rz 1,1; 1Kor 1,1; 2Kor 1,1; por. Rz 11,13; 1Kor 9,1n; 15,9). Przedstawiając się rzymskiej gminie chrześcijańskiej, której sam nie założył, napisze: „Paweł, sługa Chrystusa Jezusa, powołany apostoł, oddzielony do [głoszenia] Ewangelii Boga”. Termin ,apostoł” wyraża świadomość bycia „wysłannikiem i reprezentantem” ukrzyżowanego i zmartwychwstałego Pana9, a zarazem legitymuje urząd apostolski. Paweł ma świadomość, że jego głównym zadaniem jest głoszenie Ewangelii (1Kor 1,17a) ${ }^{10}$. Został on bowiem „oddzielony do [głoszenia] Ewangelii Boga”, to znaczy przyporządkowany do Ewangelii ${ }^{11}$, której głoszenie stało się treścią całego jego życia.

Ten zdominowany przez Pawła, Piotra i apostołów obraz ewangelizacji pierwotnego Kościoła nie byłby pełen, gdybyśmy zapomnieli o innych głosicielach dobrej nowiny o zbawieniu, którzy towarzyszą tym najbardziej znanym ewangelizatorom w ich podróżach misyjnych i sami aktywnie włączają się w dzieło przepowiadania, a których Paweł nazywa swoimi współpracownikami ${ }^{12}$. Wśród nich istotną rolę

Słowo Boże. Różnica polega na tym, że w przepowiadaniu Jezusa chodzi o »królestwo Boże«, a w kerygmacie chrześcijańskim jest nim nauczanie o Panu Jezusie Chrystusie, co jest równoznaczne z głoszeniem królestwa Bożego (Dz 28,31)".

7 Dokładnie na ten temat C. Dietzfelbinger, Die Berufung des Paulus als Ursprung seiner Theologie (WMANT 58), Neukirchen-Vluyn 1985.

8 Por. J. Zmijewski, Paulus - Knecht und Apostel Christi. Amt und Amtsträger in paulinischer Sicht, Stuttgart 1986, s. 100.

9 Tak J. A. Bühner, Art. avpo,stoloj, w: EWNT I, s. 342-351, 344.

10 Por. T. Holtz, Zum Selbstverständnis des Apostels Paulus, „Theologische Literaturzeitung“ 1966, R. 91, s. 321-330, 324-328. Paweł używa tego tytułu, gdy bezpośrednio zwraca się do pogan lub do chrześcijan pochodzenia pogańskiego (por. Rz 1,5; 11,13).

11 Tak O. Michel, Der Brief an die Römer (KEK IV $\left.{ }^{14}\right)$, Göttingen ${ }^{5} 1978$, s. 68n.

12 Dokładnie prezentuje ich W. H. Ollrog, Paulus und seine Mitarbeiter. Untersuchungen zu Theorie und Praxis der paulinischen Mission (WMANT 50), Neukirchen-Vluyn 1979 i K. Romaniuk, Uczniowie i wspótpracownicy Pawła, Warszawa 1993. 
odgrywają pary małżeńskie, o których słyszymy zarówno w Dziejach Apostolskich, jak i w listach Pawłowych.

\section{Małżeństwa apostołów}

Siódmy rozdział Pierwszego Listu do Koryntian stanowi odpowiedź Pawła na stawiane mu przez Koryntian pytania. Porusza tam kwestie dotyczące przede wszystkim małżeństwa, bezżenności, wdów, separacji, rozstania i zaręczyn. Jeżeli uwzględnimy jeszcze teksty 1 Kor 5,1-13 i 6,12-20 (por. 1 Tes 4,4), to dostrzeżemy, że Paweł odnosi się do ówczesnych realiów życia małżeńskiego w Koryncie ${ }^{13}$.

Wywody Apostoła Narodów w 1 Kor 7 z jednej strony zdradzają jego osobiste zamiłowanie do przeżywanej w sposób charyzmatyczny własnej bezżenności, a z drugiej pokazują również jego wielkie uznanie dla instytucji małżeństwa, w czasach, kiedy tak rozwody, jak i krytyczne głosy dotyczące małżeństwa, nie były rzadkością ${ }^{14}$. Apostoł nie podaje tam wprawdzie jakieś systematycznej nauki o małżeństwie. Świadczy o tym początek rozdziału: „Co do spraw, o których pisaliście...” (7,1), który wskazuje na to, że Paweł nie chce dawać jakiegoś kompendium wiedzy teoretycznej o małżeństwie i bezżenności, a także nie chce rozwiązywać problemów ludzkiej cielesności, lecz odpowiada jedynie Koryntianom na konkretne pytania i odnosi się do nurtujących ich aktualnie problemów. Na uwagę zasługuje fakt, że w równej mierze zajmuje się mężczyzną i kobietą. W w. 3-4 („Mąż niech oddaje powinność żonie, podobnie też żona mężowi. Żona nie rozporządza własnym ciałem, lecz jej mąż; podobnie też i mąż nie rozporządza własnym ciałem, ale żona") wyjaśnia, że małżeństwo oznacza również przeżywanie wspólnoty cielesnej ${ }^{15}$. Jego stwierdzenie ma charakter kategoryczny - w małżeństwie mąż i żona mają takie same, równe prawa i obowiązki ${ }^{16}$.

Odpowiadając na pytania Koryntian, Paweł wykazuje się niezwykłą trzeźwością i realizmem. Stara się też zrozumieć specyficzne i trudne sytuacje, w których znaleźli się wierni i chce wesprzeć ich swoimi radami. Dlatego podejmuje sprawy dotyczące życia małżeńskiego. W 1 Kor 7,12-14 Paweł mówi o możliwości uświęcenia

13 Por. C. G. Müller, Frühchristliche Ehepaare und paulinische Mission (SBS 215), Stuttgart 2008, s. 47.

14 Tamże.

15 Por. M. Rosik, Pierwszy List do Koryntian. Wstęp, przekład z oryginału, komentarz (NKB.NT VII), Częstochowa 2009, s. 237n.

16 Nauczanie to potwierdza np. żyjący w I w. stoicki filozof Muzoniusz Rufus, który stwierdza, że w małżeństwie wspólne życie musi odbywać się w każdej sferze i wzajemna troska małżonków o siebie. 
przez małżonka albo przez rodziców. Dla niego jest rzeczą oczywistą, że dla ludzi wierzących wszystko jest czyste i nie potrzebują oni lękać się niewierzących, to jest członków rodziny, którzy nie zostali ochrzczeni. Apostoł oczekuje raczej, że świętość świętych, to znaczy wierzących ogarnie także niewierzących (por. Ezd 9-10). Możliwość uratowania przez małżonkę czy przez małżonka będzie oceniana w 1 Kor 7,16 bardzo optymistycznie, mianowicie jako szansa i możliwość ewangelizowania. W 1 Kor 7,24 Paweł sformułuje pewnego rodzaju regułę, która pozwala zrozumieć, o co przede wszystkim mu chodzi: „Bracia, niech przeto każdy trwa u Boga w takim stanie, w jakim został powołany"17. Należy pamiętać, że pisze te słowa $\mathrm{w}$ kontekście przekonania o rychłym ponownym przyjściu Chrystusa.

O znaczeniu chrześcijańskich par małżeńskich dla misji świętego Pawła możemy przeczytać także w 1 Kor 9,5, gdzie apostoł stawia Koryntianom pytanie retoryczne: „Czyż nie wolno nam brać z sobą niewiasty-siostry, podobnie jak to czynią pozostali apostołowie oraz bracia Pańscy i Kefas?". Paweł mówi tutaj o żonach i o przysługującym mu prawie do utrzymania misjonarzy, a przede wszystkim o możliwości włączenia w dzieło ewangelizowania małżonki, której rola nie ogranicza się bynajmniej jedynie do roli gospodyni. Jak zauważa Helmut Merklein, chodzi tu o prawo utrzymania, który obejmuje również żonę i to nie tylko jako zwykłą pomoc misyjną czy jakiś personel pomocniczy, bo wówczas wystarczałoby mówić o siostrze. Żony apostołów uczestniczyły bowiem aktywnie także w pracy misyjnej i w przepowiadaniu, a zwłaszcza wchodziły w te obszary domu, które zarezerwowane były dla kobiet i nie mieli tam dostępu mężczyźni ${ }^{18}$. Wielu komentatorów uważa, że prawie wszyscy apostołowie musieli być żonaci, a jedyne znane nam wyjątki stanowili Paweł i Barnaba. Omawiany tekst 1 Kor 9,5 wskazuje bardzo wyraźnie na to, że przynajmniej z perspektywy Pawła ogromna większość apostołów była żonatymi mężczyznami i że korzystali oni z prawa do utrzymania przez wspólnoty chrześcijańskie. Jeżeli chodzi o Piotra, to należy przyjmować, że Paweł znał jego żonę osobiście, ponieważ w świetle Ga 1,18 przebywał u Piotra „piętnaście dni” w Jerozolimie. Żyjący w latach 378-444 Cyryl Aleksandryjski wyraża opinię, że dzięki żonom apostołów otwarty dla Ewangelii był dostęp do antycznych domów, które mogły być wykorzystane do

17 Więcej o tym pisze np. J. Jeremias, Die missionarische Aufgabe in der Mischehe (1 Cor 7,16), w: Neutestamentliche Studien für RudolfBultmann (BZNW 21), red. W. Eltester, Berlin - New York 1955, s. 255-279.

18 Tak H. Merklein, Der erste Brief an die Korinther. Band 2: Kapitel 5,1 - 11,1 (ÖTK 7/2), Gütersloh - Würzburg 2000, s. 217. 
celów misyjnych, czy dokładniej powiedziawszy, kobiety udostępniały i otwierały dostęp do pokojów kobiecych w domach zacnych obywateli ${ }^{19}$.

Najbardziej znany jako żonaty mężczyzna apostoł Jezusa Chrystusa to Szymon Piotr. Imię jego żony wprawdzie nie pada w ewangeliach ani w listach Pawła, ale mowa jest o jej matce - teściowej Piotra (Mk 1,29-31; Mt 8,14n; Łk 4,38n ${ }^{20}$. Ewangelia Marka, tak jak i inne ewangelie, wychodzi z oczywistego dla współczesnych ewangelistom słuchaczy i czytelników przekonania, że Piotr był żonaty i mieszkał albo w domu swojej teściowej w Kafarnaum, albo ona mieszkała u nich ${ }^{21}$. Ten drugi wariant wydaje się bardziej prawdopodobny, ponieważ dom Szymona w relacji Ewangelii wg św. Marka to także dom brata Piotra - Andrzeja (Mk 1,29). Uzdrowienie teściowej w ich domu stanowi jeden z elementów ukazania działalności Jezusa w Kafarnaum. Następne wersety (Mk 1,32-34) zaświadczają, że ten cud miał również oddziaływanie misyjne. Akcent położony jest przede wszystkim na reakcji uzdrowionej. Teściowa usługiwała im. Jej postawę rozumieć trzeba jako gotowość do służby tej kobiety. Czasownik „służyć” ( w tym kontekście interpretować jako naśladowanie Chrystusa. Jej gościnność dla Jezusa przyczynia się do umożliwienia Jego misji ${ }^{22}$. Teściowa Piotra staje się więc przykładem gotowości do służby. O tym, czy ta gotowość towarzyszyła także jej córce, żonie Piotra, ewangelia milczy. Tę gotowość do służby misyjnej należy raczej zakładać23.

O małżeństwie i rodzinie apostołów mowa jest w Nowym Testamencie jedynie w przypadku Piotra. Analogicznie można też jednak powiedzieć o diakonie Filipie, jednym z członków kolegium siedmiu (Dz 6,1-6), wybranych po to, aby „obsługiwali stoły” $(6,2)$, a apostołowie oddali się ,wyłącznie modlitwie i posłudze słowa" (6,4). Dowiadujemy się o nim w Dz 21,8, że jest ojcem czterech córek, które obdarzone były darem proroctwa. Także w jego przypadku nie pada imię jego żony i matki jego córek. Autor Dziejów Apostolskich koncentruje się przede wszystkim na prorockim darze jego córek ${ }^{24}$.

Wspomnieć należy tu również o Listach Pastoralnych (1 Tm, 2 Tm, Tt), których głównymi adresatami są chrześcijanie trzeciej albo czwartej generacji (por. Tt 1,5;

19 Por. M. Hengel, Der unterschätzte Petrus: Zwei Studien, Tübingen 2006, s. 200.

20 Por. Tenże, ,, Apostolische” Ehen und Familien, w: INTAMS review 3(1997), s. $62-$ 77, 63-65.

21 Por. Tenże, Der unterschätzte Petrus, dz. cyt., s. 171n.

22 Tak A. Hentschel, Diakonia im Neuen Testament. Studien zur Semantikunter Berücksichtigung der Rolle der Frauen (WUNT II/226), Tübingen 2007, s. 202.

23 Por. C. G. Müller, Frühchristliche Ehepaare und paulinische Mission, dz. cyt., s. 55.

24 Tamże, s. 56. 
2 Tm 2,2). Świadczą one o wielkim szacunku i powadze, jaką cieszyła się wówczas instytucja małżeństwa (por. $1 \mathrm{Tm} 5,14$; Tt 2,4n). Jako oczywisty przyjmuje się w nich fakt, że biskup powinien być żonaty (1 Tm 3,2.4; Tt 1,6) i ma być nienagannym mężem jednej żony (1 Tm 3,2; Tt 1,6). Zadaniu dawania dobrego przykładu może on sprostać jedynie wtedy, gdy będzie żył w małżeństwie. Oprócz tego musi się wykazać umiejętnością i kompetencją w wychowywaniu dzieci (1 Tm 3,4; por. $1 \mathrm{Tm} 3,12 ; \mathrm{Tt} 1,6)^{25} .1 \mathrm{Tm} 4,3$ ostrzega przed kłamcami, którzy chcieliby rezygnować z małżeństwa. Możemy tam dostrzec polemikę autora przeciw tendencjom ascetycznym przeciwników. Zawarte w Listach Pastoralnych pozdrowienia dla Akwili i Pryscylli są potwierdzeniem zaangażowania tego małżeństwa w pracę misyjną także po śmierci Pawła ${ }^{26}$.

\section{Pary małżeńskie w Rz 16}

O małżeństwach, które podobnie jak Akwila i Pryscylla angażowały się całym sercem w pracę misyjną, wspomina Paweł na liście pozdrowień w Rz 16. Pierwsze małżeństwo to Andronikos i Junia, które pozdrawia Paweł: „Pozdrówcie Andronika i Juniasa, moich rodaków i współtowarzyszy więzienia, którzy się wyróżniają między apostołami, a którzy przede mną przystali do Chrystusa"27. Apostoł przedstawia rzymskim chrześcijanom Junię i jej męża Andronikosa, posługując się czterema określeniami. Najpierw wymienia dwie cechy wspólne, które łączą go $\mathrm{z}$ małżonkami. Oboje pochodzą z tego samego, a więc z żydowskiego narodu. Oprócz tego nazwani są współtowarzyszami więzienia, to znaczy przynajmniej jeden raz podczas któregoś z licznych uwięzień Pawła (por. 2 Kor 11,23) byli z nim razem zatrzymani z powodu Ewangelii. Dalej podaje apostoł dwa dalsze określenia, którymi Andronikos i Junia wręcz go przewyższają. Oboje bowiem „wyróżniają się między apostołami”, a on jest najmniejszym z apostołów i niegodnym nazywać się apostołem, ponieważ prześladował Kościół Boży (1 Kor 15,9). Być może chce tu Paweł powiedzieć, że oboje okazali się szczególnie godnymi posiadania tytułu

25 Por. M. Hengel, „, Apostolische” Ehen, dz. cyt., s. 66.

26 Por. C. G. Müller, Frühchristliche Ehepaare und paulinische Mission, dz. cyt., s. 61.

27 Tłumaczenie Biblii Tysiąclecia posiada zamiast właściwego imienia żeńskiego „Junia” imię męskie „Junias”. Zmiany tej dokonano w XVI wieku, ponieważ nie można było sobie wyobrazić kobiety jako apostoła. Z pewnością chodzi jednak o kobietę o imieniu „Junia”. Więcej o tym pisze P. Arzt-Grabner, Junia, rehabilitierte Apostelin. Aus der Werkstatt der Exegeten: Ein textkritischer Beitrag, ,Bibel und Kirche“ 2010, nr 4, s. 243-245. 
apostoła $^{28}$. W końcu Paweł stwierdza, że chronologicznie Andronikos i Junia wcześniej niż on przyjęli wiarę w Chrystusa. Formuła przekazanego im pozdrowienia świadczy o głębokim poważaniu i szacunku, jakim cieszyli się małżonkowie w oczach apostoła ${ }^{29}$.

Warto zauważyć tutaj, że Paweł bez stawiania jakichś pytań i w sposób naturalny uznaje godność apostolską Junii, nie czyniąc żadnej różnicy wobec jej męża. Co więcej: Paweł poświadcza tę samą, wysoką pozycję obojga w gronie apostołów. Wypowiedź ta nabiera jeszcze większego znaczenia, gdy uwzględnimy jego własną świadomość apostolską ${ }^{30}$. Junia i Andronikos jako apostołowie mają więc prawo pełnić tę samą służbę głoszenia Ewangelii, co Paweł. Jeżeli nie tylko uznaje on ich apostolat, lecz stawia go ponad swoim, to możemy przyjmować, że Junia i Andronikos odnosili duże sukcesy na polu ewangelizacji ${ }^{31}$.

$\mathrm{Na}$ liście pozdrowień w Rz 16 znajdziemy także inne małżeństwo: Filologa i Julię $(16,15)$. Filolog i Julia tworzą - jak wynika z kontekstu - rdzeń rzymskiej wspólnoty Kościoła domowego. Oboje też angażują się w organizowanie i duchowe kierowanie tą wspólnotą, dzieląc między sobą obowiązki i zadania ${ }^{32}$.

\section{Filemon i Apfia (FIm 1-3)}

Małżeństwo Filemona i Apfii występuje w preskrypcie Listu do Filemona (w. 1-3). Co ciekawe, pojawia się w liście jeszcze przed wspólnotą Kościoła, która spotyka się w domu Filemona: „Paweł, więzień Chrystusa Jezusa, i Tymoteusz brat, do Filemona umiłowanego, naszego współpracownika, do Apfii, siostry, do naszego towarzysza broni Archipa i do Kościoła [gromadzącego] się w tym domu..." (w. 1-2). Wymieniona w w. 2 siostra Apfia uważana jest przez wielu komentatorów za żonę Filemona, choć nie brak i takich, którzy kwestionują ten

28 Por. C. G. Müller, Frühchristliche Ehepaare und paulinische Mission, dz. cyt., s. $38-40$.

29 Por. H. Schlier, Der Römerbrief (HThK.NT VI), Freiburg im Breisgau - Basel - Wien ${ }^{3} 1987$, s. 444-445.

30 O apostolskiej samoświadomości Pawła por. np. A. J. Najda, Der Apostel als Prophet. Zur prophetischen Dimension des paulinischen Apostolats (EHS XXIII/784), Frankfurt am Main - Berlin - Bern - Bruxelles - New York - Oxford - Wien 2004, s. 92-119.

31 Wyczerpująco o Junii i jej apostolskiej działalności w pierwotnym Kościele pisze

E. J. Epp, Junia: The First Woman Apostle, Minneapolis 2005.

32 Tak C. G. Müller, Frühchristliche Ehepaare und paulinische Mission, dz. cyt., s. 41. 
fakt ${ }^{33}$. Jeżeli uwzględnimy jednak cały list, to Filemon jawi się jako jedyny adresat tego pisma. Jednakże wymienienie również innych adresatów wskazuje na to, że list ten nie jest tylko pismem prywatnym. Głównym powodem jego napisania była prośba o przyjęcie niewolnika Onezyma jako „umiłowanego brata” (w. 16). Jeżeli Apfia zaliczana jest do adresatów listu, to rodzi się pytanie, czy Paweł znał ją osobiście. $Z$ całą pewnością występuje ona we wspólnocie Kościoła i ma tam znaczącą pozycję $e^{34}$. To, że Paweł wymienia Apfię obok właściwego adresata listu może świadczyć również o tym, że mogłaby pomóc w sprawie jego prośby dotyczącej Onezyma.

Apfia nazwana została „,siostrą", jednakże ten atrybut w terminologii Pawła nie wskazuje na jakąś aktywną pracę czy odpowiedzialną funkcję we wspólnocie. Nazwanie konkretnych, wymienionych po imieniu osób mianem „siostry” lub „brata”, jak np. Febe (Rz 16,1), Sostenesa (1 Kor 1,1), Apollosa (1 Kor 16,12), Tymoteusza (2 Kor 1,1; Flm 1,1; 1 Tes 3,2) i Epafrodyta (Flp 2,25) oznacza w listach Pawłowych zwykłe zbiorowe określenie członków wspólnoty chrześcijańskiej jako $\alpha \dot{\delta} \in \lambda \phi o \iota$, czyli braci i sióstris ${ }^{35}$.

Apostoł, nazywając kogoś bratem lub siostrą, ma na myśli więzi braterskie czy rodzinne z ludźmi i między ludźmi, którzy tak jak on przyznają się do wiary w Jezusa Chrystusa. Tam zaś, gdzie Paweł chce zwrócić uwagę na pełnione przez kogoś we wspólnocie zadania, do określenia „brat” lub „siostra” dodaje odnoszące się do funkcji atrybuty, jak np. ,sługa Boży” i „pomocnik” (1 Tes 3,2), „diakonisa” (Rz 16,1n) czy „współpracownik i współbojownik” (Flp 2,25). Określenie więc Apfii jako „siostra” w Flm 2 świadczy jedynie o jej przynależności do grupy osób wierzących w Chrystusa ${ }^{36}$.

33 Por. B. Adamczewski, List do Filemona. Wstęp, przekład z oryginału, komentarz (NKB.NT XII), Częstochowa 2006, s. 57.

34 Por. S. Bieberstein, Der Brief an Philemon. Brieflektüre unter den kritischen Augen Aphias, w: L. Schottroff - M. T. Wacker (red.), unter der Mitarbeit von C. Janssen und B. Wehn, Kompendium Feministische Bibelauslegung, Gütersloh ${ }^{2} 1999$, s. 677.

35 A. Hentschel, Diakonia im Neuen Testament, dz. cyt., s. 168, uważa, że określenie kogoś mianem „brata” lub „siostry” oznacza również jego/ jej zaangażowanie we wspólnocie lub w pracy misyjnej.

36 Por. M. Leutsch, Apphia, Schwester!, w: Für Gerechtigkeit streiten. Theologie im Alltag einer bedrohten Welt. Festschrift für L. Schottroff, red. D. Sölle, Gütersloh 1994, s. 76-82, 79. Por. też C. G. Müller, Frühchristliche Ehepaare und paulinische Mission, dz. cyt., s. 43-46. 


\section{Akwila i Pryscylla}

Najwięcej informacji o działalności misyjnej chrześcijańskich małżeństw posiadamy o Akwili i Pryscylli, których Paweł nazywa swoimi współpracownikami. Oboje - możemy powiedzieć za Christophem Gregorem Müllerem - poświęcili swoje życie misji ewangelizacji ${ }^{37}$. Ze względu na ich podróże i zmiany miejsca zamieszkania podyktowane służbą Ewangelii małżeństwo to nazwać można „mobilną parą" 38 .

Na kartach Nowego Testamentu nie znajdujemy jakiegoś długiego i dokładnego opowiadania o Akwili i Pryscylli. Jest o nich mowa przede wszystkim w Dziejach Apostolskich 18,1-3. 18-19. 26, ale także w listach Pawłowych 1Kor 16,19, Rz 16,3-5 oraz w 2 Tm 4,19; zawsze wymienieni są razem. Dz 18,2 precyzują ponadto, że Akwila i Pryscylla są małżeństwem. Nic nie wiemy natomiast o tym, czy mieli dzieci, czy też nie.

Mówiąc o Pryscylli, Paweł używa greckiej formy łacińskiego imienia Pri,ska (Rz 16,3; 1Kor 16,19) ${ }^{39}$, które tłumaczy się „czcigodna”. W Dziejach Apostolskich

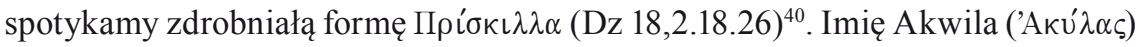

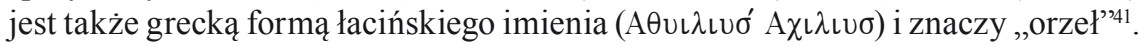
To imię otrzyma w jego życiu, jak również w życiu jego małżonki, znaczenie programowe i metaforyczne - oboje będą bowiem jak ów podróżujący ptak i staną się ,,symbolem siły i wytrwania" ${ }^{\prime 2}$.

Godnym zauważenia jest także fakt, że gdy w Nowym Testamencie występują imiona Pryscylli i Akwili, częściej na pierwszym miejscu wymienia się Pryscyllę (Dz 18,18.26; Rz 16,3; 2Tym 4,19), mimo że jest kobietą. Tylko w Dz 18,2 i 1Kor 16,19 pierwszy nazwany jest Akwila ${ }^{43}$. To przestawienie kolejności, które zapewne nie jest przypadkowe, dało pole do wielu przypuszczeń. Czyżby Pryscylla należała

37 Por. C. G. Müller, Priska und Aquila. Der Weg eines Ehepaares und die paulinische Mission, „Münchener Theologische Zeitschrift“ 2003, R. 54, s. 195-210.

38 Tak W.H. Ollrog, Paulus und seine Mitarbeiter, dz. cyt., s. 26 n.

39 Forma ta występuje również w $2 \operatorname{Tm} 4,19$.

40 Por. D. Oppel, Priska, w: Neues Bibel-Lexikon III, red. M. Görg - B. Lang, Zürich Düsseldorf 2001, s. 172.

41 Por. M. Görg, Aquila, w: Neues Bibel-Lexikon I, red. M. Görg - B. Lang, Zürich Düsseldorf 1991, s. 142.

42 M. Lurker, Słownik obrazów i symboli biblijnych, Poznań 1989, s. 161.

43 Por. A. Weiser, VAku,laj-Pri,ska, Pri,skilla, w: H. Balz - G. Schneider (red.), w: EWNT I, 134n. 
do wyższej klasy społecznej niż jej mąż ${ }^{44}$ A może wcześniej niż jej mąż stała się chrześcijanką? Czy jest to tylko „forma uznania dla niezwykłości tej kobiety”45? Heinrich Schlier widzi w tym przestawieniu wskazanie na „większą rolę tej kobiety w gminie chrześcijańskiej”46, Alfons Weiser zaś wskazanie na jej „bardziej znaczącą rolę we wspólnotach domowych" ${ }^{\text {’47 }}$.

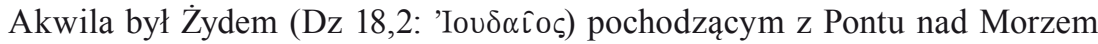
Czarnym, na co jednoznacznie wskazuje wyrażenie „rodem Pontyjczyka” w Dz 18,2 (por. Dz 4,36; 18,24). Filon z Aleksandrii w Legatio ad Gaium (§ 36) zaświadcza, że w owym czasie istniała w Poncie diaspora żydowska. Nie wiemy jednak, kiedy i dlaczego Akwila przeniósł się do Rzymu. W każdym bądź razie zmiana miejsca jego pobytu nie była czymś niezwykłym lub odosobnionym. Na liście narodów (Dz 2,9-11) przybyłych do Jerozolimy na dzień Pięćdziesiątnicy wymienieni są również ludzie z Pontu. Wiemy natomiast, że Akwila z Pontu przeniósł się do Rzymu, gdzie należał z pewnością do licznego grona przybyszów z prowincji. Po ogłoszeniu edyktu cesarza Klaudiusza (w roku 49) nakazującego Żydom opuścić Rzym udał się do Koryntu, potem do Efezu, by ponownie wrócić do Rzymu. O jego żonie Pryscylli wiadomo zaś bardzo niewiele. Dzieje Apostolskie nie mówią nam nic o jej pochodzeniu. Może tak jak jej mąż pochodziła z Pontu, a może była Rzymianką? To milczenie na temat pochodzenia Pryscylli tłumaczyć można podwójnym kręgiem adresatów Dziejów Apostolskich, jak również tym, że rzymska gmina chrześcijańska znajdowała się zarówno pod wpływem judeochrześcijan, jak i chrześcijan pochodzenia pogańskiego ${ }^{48}$.

Akwila i Pryscylla wykonują ten sam lub przynajmniej podobny zawód, co apostoł Paweł. W Dz 18,3 czytamy: ,a ponieważ [Paweł] znał to samo rzemiosło, zamieszkał u nich [u Pryscylli i Akwili] i pracował; zajmowali się wyrobem namiotów”. Jako rzemieślnicy Akwila i Pryscylla nie mogli cieszyć się w świecie antycznym jakimś szczególnym poważaniem, a częściej musieli spotykać się z pogardą innych, ponieważ porządek społeczny tamtych czasów z reguły zaliczał

44 Na taką możliwość wskazuje R. Schumacher, Aquila und Priscilla, „Theologie und Glaube" 1920, nr 12, s. 86-99, 88.

45 Tak K. Romaniuk, Święty Paweł o kobietach, „Wrocławskie Studia Teologiczne” 1992-1993, R. 21-22, s. 51-98, 83.

46 H. Schlier, Der Römerbrief, dz. cyt., s. 443.

47 A. Weiser, Die Rolle der Frau in der urchristlichen Mission, w: G. Dautzenberg H. Merklein - K. Müller (red.), Die Frau im Urchristentum (QD 95), Freiburg in Breisgau 1983, s. 158-181, 173.

48 Tak C. G. Müller, Priska und Aquila, dz. cyt., 200. Por. także A. Paciorek, Pawet Apostot - Pisma, cz. 1, Tarnów 1995 (Academica 28), s. 190-192. 
rzemieślników do „małych ludzi” ${ }^{\text {’49 }}$. Oboje małżonkowie pracują jako wytwórcy namiotów albo rymarze, najprawdopodobniej samodzielnie, we własnym zakładzie.

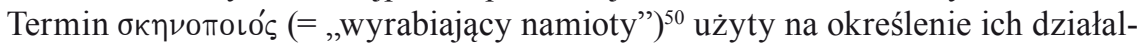
ności jest $\eta \alpha \pi \alpha \xi \lambda \in \gamma o \mu \in \nu \circ \nu$ w Nowym Testamencie i oznacza rzemieślnika, który zajmuje się wytwarzaniem płatów skóry oraz łączeniem ich w większe całości, tak że powstawały z tego namioty, ale również inne przykrycia np. do straganów na rynku czy teatrów ${ }^{51}$. Akwila i Pryscylla wykonywali więc pracę z pogranicza rymarstwa, krawiectwa i szewstwa ${ }^{52}$. Praca ta - według świadectwa Pawła - była bardzo ciężka (1Kor 4,12), wymagała wysiłku „dniem i nocą” (1Tes 2,9).

Jak już wspomnieliśmy Akwila był Żydem, który wraz ze swoją żoną Pryscyllą mieszkał najpierw w Rzymie (Dz 18,2) $)^{53}$. Dzieje Apostolskie nie podają jednak ani miejsca ani czasu, kiedy Akwila i Pryscylla przyjęli wiarę chrześcijańską. Jednakże ich dalsze życie, a przede wszystkim ich pełne determinacji misjonarskie zaangażowanie w głoszenie Ewangelii w Koryncie, dokąd się następnie udali, pozwala przyjmować, że małżonkowie Akwila i Pryscylla już w Rzymie stali się chrześcijanami i już tam należeli do osób kierujących miejscową gminą judeochrześcijańską ${ }^{54}$. Warto też dodać, że również określenie Akwili mianem

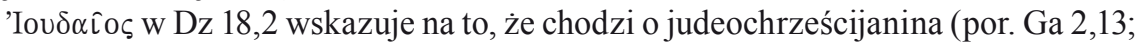
Dz 21,20$)^{55}$. Gdy wybuchły zamieszki ${ }^{56}$, spowodowane najprawdopodobniej ,,przez przybycie do Rzymu chrześcijańskich misjonarzy"57, Akwila i Pryscylla jako Żydzi zostali wypędzeni z miasta na skutek edyktu cesarza Klaudiusza z roku 49. Nie

49 H. Klot, Die Wirtschaft der griechisch-römischen Welt. Eine Einführung, Darmstadt 1992, 214.

50 Por. W. Michaelis, skhnh, ktl), w: ThWNT VII, 369-396, 394nn.

51 Por. P. Lampe, Paulus - Zeltmacher, „Biblische Zeitschrift. Neue Folge“ 1987, R. 31, s. 256-261, 258n.

52 Por. K. Romaniuk, Uczniowie i wspótpracownicy Pawła, dz. cyt., s. 9.

53 Szacunkowa liczba Żydów w Rzymie w tamtym czasie wynosiła od 30 do 60 tysięcy osób. Por. D. A. Cineira, Die Religionspolitik des Kaisers Claudius und die paulinische Mission (HBS 19), Freiburg in Breisgau 1988, s. 193.

54 Tak np. R. Pesch, Die Apostelgeschichte. 2. Teilband. Apg 13 - 28 (EKK V/2), Zürich - Einsiedeln - Köln - Neukirchen-Vluyn 1986, s. 147.

55 Tak C. G. Müller, Priska und Aquila, dz. cyt., s. 202.

56 O zamieszkach tych informuje Swetoniusz w „Vita Klaudii” (25,4): „[Klaudiusz] wypędził Żydów z Rzymu, ponieważ podburzani przez Chrestosa byli sprawcami ustawicznych zamieszek".

57 D. A. Cineira, Die Religionspolitik des Kaisers Claudius und die paulinische Mission, dz. cyt., s. 205. 
zatrzymali się gdzieś w okolicach Rzymu, aby zobaczyć jak rozwinie się sytuacja i ewentualnie powrócić do miasta, lecz opuścili Italię i przenieśli się do Koryntu.

Późną jesienią 49 roku Akwila i Pryscylla otworzyli w Koryncie swój zakład rzemieślniczy. W tym samym czasie lub na początku roku 50 - na co wskazuje

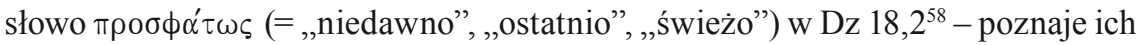
apostoł Paweł, który podczas swojej drugiej wyprawy misyjnej w Koryncie czeka na przybycie z Berei Sylwana i Tymoteusza. Jeżeli jednak Paweł chciał stąd udać się do Rzymu (por. Rz 1,13; 15,22), to wiadomość o edykcie cesarza Klaudiusza przeszkodziła mu w realizacji tych planów misyjnych ${ }^{59}$. Akwila i Pryscylla przebywali w Koryncie już jako chrześcijanie, i to od początku, niezależnie od Pawła. W takim wypadku Paweł nie jest pierwszym chrześcijaninem, który przybył do Koryntu, jeżeli nawet rozumie siebie jako założyciela gminy chrześcijańskiej (por. 1Kor 3,6.10; 4,14-16), który ,jako roztropny budowniczy” położył fundament $(1 \text { Kor } 3,10)^{60}$.

Chrześcijańskie małżeństwo - oferując apostołowi mieszkanie i pracę w ich domu - stwarza mu idealną możliwość pracy misyjnej w Koryncie. Paweł skorzystał z gościnności Akwili i Pryscylli, zatrzymał się u nich, poświęcając się pracy w warsztacie, a w szabat oddawał się głoszeniu Ewangelii (Dz 18,3n). Dom Akwili i Pryscylli nie był jednak tylko miejscem mieszkania i pracy, lecz również - podobnie jak inne warsztaty w tamtym czasie - dawał okazję do spotykania różnych osób i do nawiązywania $z$ nimi kontaktów ${ }^{61}$. Przede wszystkim dom ich był miejscem spotkań wspólnoty chrześcijańskiej, podstawową komórką wspólnoty domowej ${ }^{62}$. Akwila i Pryscylla, otwierając swój dom dla chrześcijan, tworzą „,rdzeń Kościoła, który jako wspólnota regularnie gromadzi się w ich mieszkaniu na modlitwę, ucztę i sprawowanie Eucharystii” ${ }^{63}$. Można także zakładać, że jako właściciele domu małżonkowie mieli „eksponowaną pozycję oraz pewną funkcję kierowniczą" ${ }^{64}$ na

58 C. G. Müller, Priska und Aquila, dz. cyt., 202.

59 D. A. Cineira, Die Religionspolitik des Kaisers Claudius und die paulinische Mission, dz. cyt., 213.

60 Por. A. J. Najda, Der Apostel als Prophet..., dz. cyt., 102n.

${ }_{61}$ Por. H. J. Klauck, Hausgemeinde und Hauskirche im frühen Christentum, „Theologisches Jahrbuch(L)”, 1985, nr 10, s. 144-213, 151.

62 O roli domów w pierwotnym Kościele por. J. Gnilka, Die urchristliche Hausgemeinde (Festvortrag), w: Eduard Schick (1906-2000). Gedenkfeier der Theologischen Fakultät Fulda. Mit einer Biographie und Vita (FHSS 39), Frankfurt am Main 2001.

63 H. J. Klauck, Gemeinde zwischen Haus und Stadt. Kirche bei Paulus, Freiburg in Breisgau 1992, s. 28.

64 T. Schmeller, Hierarchie und Egalität. Eine sozialgeschichtliche Untersuchung paulinischer Gemeinden und griechisch-römischer Vereine (SBS 162), Stuttgart 1995, s. 60. 
zebraniach wspólnoty. Chodzi tu głównie o modlitwę, przepowiadanie, proroctwo oraz funkcje liturgiczne.

Po upływie około półtora roku Akwila i Pryscylla opuszczają Korynt i wraz z Pawłem statkiem odpływają do Efezu (Dz 18,18). Dzieje Apostolskie nie podają powodów ich wyjazdu. Może zostali zamieszani w konflikt Pawła z Żydami, którego finałem była rozprawa sądowa przed prokonsulem Galionem (por. Dz 18,1217). Sprawa ta zakończyła się pomyślnie dla apostoła i później jeszcze przez jakiś czas Paweł pozostawał w Koryncie ${ }^{65}$. Nie wiemy też, czym zajmowali się Akwila i Pryscylla w Efezie. Możemy tylko przypuszczać, że otworzyli swój warsztat i wykonywali swoje rzemiosło, aby umożliwić Pawłowi działalność misyjną ${ }^{66}$. W każdym bądź razie po przybyciu do Efezu chrześcijańscy małżonkowie włączyli się w dzieło ewangelizacji. Tak jak czynił to Apostoł Narodów, udali się najpierw do synagogi i uczestniczyli tam w liturgii. Spotkali tam pewnego Żyda z Aleksandrii imieniem Apollos, który był człowiekiem uczonym i znającym świetnie Pisma (Dz 18,24). „Znał on już drogę Pańską, przemawiał z wielkim zapałem i nauczał dokładnie tego, co dotyczyło Jezusa, znając tylko chrzest Janowy. Zaczął on odważnie przemawiać w synagodze" (Dz 18,25n). Gdy Pryscylla i Akwila usłyszeli jego mowę, postanowili zaangażować Apollosa w głoszenie Ewangelii. Zaprosili go do swojego domu (Dz 18,26) ${ }^{67}$ i postanowili go ,jeszcze dokształcić" ${ }^{68}$, bo Apollos, choć „uczony i znający świetnie Pisma” (Dz 18,24), znał tylko chrzest

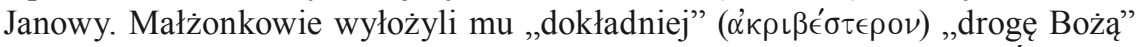

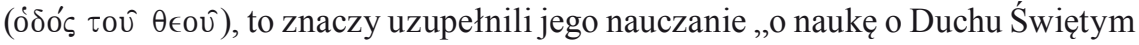
i o chrzcie w imię Jezusa" "99. Innymi słowy Akwila i Pryscylla wyłożyli Apollosowi „bardziej rozwiniętą teologię Pawłową i jej historiozbawczy sens o drodze Bożej do Żydów i pogan"70. Poprzez pouczenie współpracowników Apostoła Narodów Apollos otrzymał ,status ucznia Pawła" ${ }^{71}$.

Podobnie jak w Koryncie, tak i w Efezie, dom Akwili i Pryscylli „służył potrzebom wspólnym gminy: to u nich właśnie zbierano się na wspólne modlitwy i tak dom ich stał się jednym z wielu wczesnochrześcijańskich Kościołów

65 Por. K. Romaniuk, Uczniowie i współpracownicy Pawła, dz. cyt., s. 11n.

66 Por. R., Die Apostelgeschichte, dz. cyt., s. 161.

${ }_{67}$ Por. J. Zmijewski, Die Apostelgeschichte (RNT), Regensburg 1994, s. 677.

68 K. Romaniuk, Uczniowie i wspótpracownicy Pawła, dz. cyt., s. 13.

69 J. Roloff, Die Apostelgeschichte (NTD 5 ${ }^{18}$ ), Göttingen - Zürich ${ }^{2} 1988,279$.

70 R. Pesch, Die Apostelgeschichte, dz. cyt., s. 161n.

71 W. Thiessen, Christen in Ephesus. Die historische und theologische Situation in vorpaulinischer und paulinischer Zeit und zur Zeit der Apostelgeschichte und der Pastoralbriefe (TANZ 12), Tübingen 1995, s. 49n. 
domowych"72, który obejmował swoim zasięgiem wielu wiernych (1 Kor 16,19). Warto też zauważyć, że według Dziejów Apostolskich w domu małżeństwa Akwili i Pryscylli gościem jest nie tylko Paweł, lecz także Apollos, który w pierwszych czterech rozdziałach Pierwszego Listu do Koryntian jawi się jako rywal Apostoła Narodów. Można więc odnieść wrażenie, że chrześcijańskie małżeństwo pełni rolę łagodzącą między dwoma misjonarzami ${ }^{73}$. Sprawą najważniejszą jest dla nich bowiem głoszenie Ewangelii.

Pobyt Pawła w Efezie w relacji Dziejów Apostolskich $(20,31)$ trwał trzy lata. Prawdopodobnie tak długo pozostawali tam też Akwila i Pryscylla. Powrót wypędzonych z Rzymu Żydów i judeochrześcijan stał się możliwy dopiero po śmierci cesarza Klaudiusza w październiku $54 \mathrm{roku}^{74}$. Z okazji tej skorzystali między innymi Akwila i Pryscylla. Powrócili do Rzymu ze względu na Pawła i jego misję ewangelizacyjną - mieli przygotować mu pole do działalności w Rzymie. Tak jak w Koryncie i w Efezie zatroszczyli się o mieszkanie i środki potrzebne do życia i pracy dla apostoła, tym bardziej, że Rzym miał być dla niego tylko etapem w drodze do Hiszpanii (por. Rz 15,24). Paweł chciał bowiem „głosić Ewangelię jedynie tam, gdzie imię Chrystusa było jeszcze nieznane" (Rz 15,20). Uwzględniając zaś tekst pozdrowień dla Pryscylli i Akwili w Rz 16,3-5 można zakładać, że małżeństwo to wróciło do Wiecznego Miasta w czasie po powstaniu Pierwszego Listu do Koryntian (między 52 a 55 rokiem), a przed powstaniem Listu do Rzymian (rok 55 lub 56). Wyrażenie „Kościół w ich domu” w Rz 16,5 świadczy o tym, że i w Rzymie, jeszcze przed przybyciem tam Pawła, w domu Akwili i Pryscylli gromadził się Kościół na sprawowanie Eucharystii, a małżonkowie pełnili prawdopodobnie funkcje kierownicze na zebraniach liturgicznych ${ }^{75}$.

Akwila i Pryscylla działają jako para ewangelizatorów, zawsze wymieniani są razem. Fakt ten nie dziwi, i to nie tylko z tego powodu, że są małżeństwem (Dz $18,2)$. W Nowym Testamencie często mamy do czynienia z posłaniem pary uczniów przez Jezusa. Tak np. czytamy w Mk 6,7: „Następnie przywołał do siebie Dwunastu i zaczął rozsyłać ich po dwóch” (por. Mk 11,1n; 14,13), czy w Łk 10,1: „Następnie wyznaczył Pan jeszcze innych siedemdziesięciu dwóch i wysłał ich po dwóch przed sobą do każdego miasta i miejscowości, dokąd sam przyjść zamierzał" (por. Łk

72 K. Romaniuk, Uczniowie i współpracownicy Pawła, dz. cyt., s. 84.

73 Por. C.G. Müller, Priska und Aquila, dz. cyt., s. 203.

74 Por. P. Stuhlmacher, Der Brief an die Römer (NTD $\left.{ }^{14}\right)$, Göttingen 1989, s. 13.

75 Tak uważa np. H. Merklein, Im Spannungsfeld zwischen Protologie und Eschatologie. Zur kurzen Geschichte der aktiven Beteiligung von Frauen in paulinischen Gemeinden, w: Eschatologie und Schöpfung. Festschrift für E. Gräßer (BZNW 89), red. M. Evang H. Merklein - M. Wolter, Berlin - New York 1997, s. 231-259, 247. 
19,29n.32; 22,8). Spotykamy też pary braci: Szymona i Andrzeja (Mk 1,16-18; Mt 4,18-20) ${ }^{76}$, czy też Jakuba i Jana, synów Zebedeusza (Mk 1,19n; Mt 4,21n). Posyłanie dwóch osób związane jest z żydowskim prawem o świadku: „Nie przyjmie się zeznania jednego świadka przeciw nikomu, w żadnym przestępstwie i w żadnej zbrodni. Lecz każda popełniona zbrodnia musi być potwierdzona zeznaniem dwu lub trzech świadków" (Pwt 19,15). Dlatego też w Dziejach Apostolskich na misję głoszenia Ewangelii szło zazwyczaj dwóch misjonarzy: Piotr i Jan (Dz 3,1; 8,14), Paweł i Barnaba (Dz 13,1-5), Barnaba i Marek (Dz 15,39), Paweł i Sylas (Dz 15,40), Tymoteusz i Erast (Dz 19,22). Chodziło przy tym o potwierdzenie i zwiększenie wiarygodności głoszonej nauki przez drugą posłaną osobę ${ }^{77}$.

Żadna z par małżeńskich nie odegrała jednak tak ważnej roli w misji Apostoła Narodów, jak Akwila i Pryscylla. To właśnie ich jako pierwszych ze wspólnoty chrześcijan w Rzymie pozdrawia Paweł, pisząc w Rz 16,3-5a: „Pozdrówcie współpracowników moich w Chrystusie Jezusie, Pryskę i Akwilę, którzy za moje życie nadstawiali swe głowy i którym winienem wdzięczność nie tylko ja sam, ale i wszystkie Kościoły nawróconych pogan. Pozdrówcie też Kościół, który się zbiera w ich domu”. Apostoł określa ich mianem „współpracowników”, chcąc w ten sposób podkreślić zaangażowanie obojga małżonków w głoszenie Ewangelii. Akwila i Pryscylla rozpoczęli to głoszenie niezależnie od Pawła, później - od czasu ich pobytu w Koryncie - ściśle współpracowali z Apostołem Narodów. Szli niejako krok przed nim i byli jego „poprzednikami”. Paweł nawiązywał do nich i ich nauczania, przede wszystkim zaś zwracał się do utworzonych już przez nich wspólnot Kościoła domowego w Koryncie, w Efezie (1Kor 16,19) i w Rzymie (Rz 16,5)

Nie tylko pierwsze miejsce na liście pozdrowień Pawła, lecz także jego osobista wdzięczność, świadczą o wielkim zaangażowaniu Akwili i Pryscylli w misją głoszenia Ewangelii. Oboje małżonkowie „nadstawiali swe głowy” (Rz 16,4) za życie apostoła. To sformułowanie oznacza ,przyjęcie niebezpieczeństwa utraty życia lub jakiejś wielkiej ofiary"79. Kiedy i gdzie mogło mieć to miejsce? Analizując życiorys Pawła, możemy myśleć o wspomnianych przez niego w 2 Kor 6,4n czy w 2 Kor 11,23-2780 niebezpieczeństwach w jego działalności apostolskiej, lub też o sporach, które towarzyszyły jego pobytowi w Efezie (por. Dz 18,12; 19,23;

76 W J 1,40-42 mowa jest o braciach w innej kolejności, mianowicie o Andrzeju i Szymonie.

77 Por. J. Jeremias, Paarweise Sendung im Neuen Testament, w: tenże, Abba. Studien zur neutestamentlichen Teologie und Zeitgeschichte, Göttingen 1966, s. 132-139.

78 Por. C. G. Müller, Priska und Aquila, dz. cyt., s. 208.

79 R. Schumacher, Aquila und Priscilla, dz. cyt., s. 94.

80 Por. A. J. Najda, Der Apostel als Prophet..., dz. cyt., s. 159nn. 
2Kor 1,8$)^{81}$. Apostoł dodaje, że swoją wdzięczność winny Akwili i Pryscylli także „wszystkie Kościoły nawróconych pogan” (Rz 16,4).

\section{Inspiracja dla chrześcijańskich malżeństw}

Podejmując próbę podsumowania działalności ewangelizacyjnej chrześcijańskich małżeństw - zwłaszcza Akwili i Pryscylli - należy stwierdzić, że w pierwotnym Kościele odegrały one istotną rolę w głoszeniu Ewangelii i budowaniu wspólnot kościelnych ${ }^{82}$. Małżonkowie byli nie tylko gospodarzami, dobroczyńcami czy pracodawcami misjonarzy, lecz przede wszystkim ich współpracownikami w głoszeniu Ewangelii. Często to oni dają materialne zaplecze dla działalności ewangelizatorów i przygotowują pole do ich pracy misyjnej. Potrafią też - co warto zauważyć i podkreślić - usunąć się w odpowiednim momencie, powierzając dzieło ewangelizacji powołanym do tego przez Jezusa Chrystusa apostołom, jak uczynili to Akwila i Pryscylla wobec Pawła. Domy chrześcijańskich małżonków były zawsze gościnne i otwarte dla głosicieli Ewangelii oraz dla wielu innych, którzy poszukują Chrystusa. W ich domach gromadzili się chrześcijanie na wspólną modlitwę oraz na sprawowanie Eucharystii, a sami małżonkowie chętnie angażowali się w liturgię oraz przejmowali kierownicze funkcje we wspólnocie. Poświęcając się całkowicie Jezusowi Chrystusowi i głoszeniu Jego Ewangelii, małżonkowie ryzykowali nawet swoim życiem. Ich postawa jest zachętą i zaproszeniem innych małżeństw chrześcijańskich do aktywnego włączenia się w dzieło ewangelizacji.

\section{Literatura}

Adamczewski B., List do Filemona. Wstęp, przekład z oryginatu, komentarz (NKB. NT XII), Częstochowa 2006.

Arzt-Grabner P., Junia, rehabilitierte Apostelin. Aus der Werkstatt der Exegeten: Ein textkritischer Beitrag, „Bibel und Kirche“ 2010, nr 4, s. 243-245.

Bieberstein S., Der Brief an Philemon. Brieflektüre unter den kritischen Augen Aphias, w: L. Schottroff-M. T. Wacker (red.), unter der Mitarbeit von C. Janssen und B. Wehn, Kompendium Feministische Bibelauslegung, Gütersloh ${ }^{2} 1999$.

Bühner J. A., Art. avpo,stoloj, w: EWNT I, s. 342-351, 344.

Cineira D. A., Die Religionspolitik des Kaisers Claudius und die paulinische Mission (HBS 19), Freiburg in Breisgau 1988.

81 Por. U. Wilckens, Der Brief an die Römer. 3. Teilband. Röm 12 - 16 (EKK VI/3), Zürich - Einsiedeln - Köln - Neukirchen-Vluyn 1982, s. 134.

82 Tak M. Theobald, Römerbrief. Kapitel 12-16 (SKK.NT 6/2), Stuttgart 2001, s. 229n. 
Dietzfelbinger C., Die Berufung des Paulus als Ursprung seiner Theologie (WMANT 58), Neukirchen-Vluyn 1985.

Epp E. J., Junia: The First Woman Apostle, Minneapolis 2005.

Gnilka J., Die urchristliche Hausgemeinde (Festvortrag), w: Eduard Schick (19062000). Gedenkfeier der Theologischen Fakultät Fulda. Mit einer Biographie und Vita (FHSS 39), Frankfurt am Main 2001.

Görg M., Aquila, w: Neues Bibel-Lexikon I, red. M. Görg - B. Lang, Zürich Düsseldorf 1991.

Haręzga S., Eklezjologia, w: Teologia Nowego Testamentu. Tom I. Ewangelie synoptyczne i Dzieje Apostolskie, red. M. Rosik, Wrocław 2008.

Hengel M., ,Apostolische” Ehen und Familien, w: INTAMS review 3(1997), s. 62-77.

Hengel M., Der unterschätzte Petrus: Zwei Studien, Tübingen 2006.

Hentschel A., Diakonia im Neuen Testament. Studien zur Semantikunter Berücksichtigung der Rolle der Frauen (WUNT II/226), Tübingen 2007.

Holtz T., Zum Selbstverständnis des Apostels Paulus, „Theologische Literaturzeitung“ 1966, R. 91, s. 321-330, 324-328.

Jeremias J., Die missionarische Aufgabe in der Mischehe (1 Cor 7,16), w: Neutestamentliche Studien für Rudolf Bultmann (BZNW 21), red. W. Eltester, Berlin - New York 1955, s. 255-279.

Jeremias J., Paarweise Sendung im Neuen Testament, w: tenże, Abba. Studien zur neutestamentlichen Teologie und Zeitgeschichte, Göttingen 1966, s. 132-139.

Klauck H. J., Gemeinde zwischen Haus und Stadt. Kirche bei Paulus, Freiburg in Breisgau 1992.

Klauck H. J., Hausgemeinde und Hauskirche im frühen Christentum, „Theologisches Jahrbuch(L)", 1985, nr 10, s. 144-213.

Klot H., Die Wirtschaft der griechisch-römischen Welt. Eine Einführung, Darmstadt 1992.

Lampe P., Paulus - Zeltmacher, „Biblische Zeitschrift. Neue Folge” 1987, R. 31, s. 256-261.

Langkammer H., Kerygmat paschalny w Ewangeliach i Dziejach Apostolskich, Radom 2010.

Leutsch M., Apphia, Schwester!, w: Für Gerechtigkeit streiten. Theologie im Alltag einer bedrohten Welt. Festschrift für L. Schottroff, red. D. Sölle, Gütersloh 1994, s. 76-82.

Lurker M., Stownik obrazów i symboli biblijnych, Poznań 1989.

Merklein H., Im Spannungsfeld zwischen Protologie und Eschatologie. Zur kurzen Geschichte der aktiven Beteiligung von Frauen in paulinischen Gemeinden, 
w: Eschatologie und Schöpfung. Festschrift für E. Gräßer (BZNW 89), red.

M. Evang - H. Merklein - M. Wolter, Berlin - New York 1997, s. 231-259, 247. Merklein H., Der erste Brief an die Korinther. Band 2: Kapitel 5,1 - 11,1 (ÖTK 7/2), Gütersloh - Würzburg 2000.

Michaelis W., Art. o'do,j ktl., w: ThWNT V, s. 93-95.

Michaelis W., skhnh, ktl), w: ThWNT VII, s. 369-396.

Michel O., Der Brief an die Römer (KEK IV ${ }^{14}$ ), Göttingen ${ }^{5} 1978$.

Müller C. G., Frühchristliche Ehepaare und paulinische Mission (SBS 215), Stuttgart 2008.

Müller C. G., Priska und Aquila. Der Weg eines Ehepaares und die paulinische Mission, „Münchener Theologische Zeitschrift“ 2003, R. 54, s. 195-210.

Najda A. J., Der Apostel als Prophet. Zur prophetischen Dimension des paulinischen Apostolats (EHS XXIII/784), Frankfurt am Main - Berlin - Bern Bruxelles - New York - Oxford - Wien 2004, s. 92-119.

Ollrog W. H., Paulus und seine Mitarbeiter. Untersuchungen zu Theorie und Praxis der paulinischen Mission (WMANT 50), Neukirchen-Vluyn 1979.

Oppel D., Priska, w: Neues Bibel-Lexikon III, red. M. Görg - B. Lang, Zürich Düsseldorf 2001.

Paciorek A., Pawet Apostot - Pisma, cz. 1, Tarnów 1995 (Academica 28).

Pesch R., Die Apostelgeschichte. 2. Teilband. Apg 13 - 28 (EKK V/2), Zürich Einsiedeln - Köln - Neukirchen-Vluyn 1986.

Roloff J., Die Apostelgeschichte (NTD $5^{18}$ ), Göttingen - Zürich ${ }^{2} 1988$.

Romaniuk K., Swięty Pawet o kobietach, „Wrocławskie Studia Teologiczne” 19921993, R. 21-22, s. 51-98.

Romaniuk K., Uczniowie i wspótpracownicy Pawła, Warszawa 1993.

Rosik M., Pierwszy List do Koryntian. Wstęp, przekład z oryginału, komentarz (NKB.NT VII), Częstochowa 2009.

Schlier H., Der Römerbrief (HThK.NT VI), Freiburg im Breisgau - Basel - Wien ${ }^{3} 1987$.

Schmeller T., Hierarchie und Egalität. Eine sozialgeschichtliche Untersuchung paulinischer Gemeinden und griechisch-römischer Vereine (SBS 162), Stuttgart 1995.

Schnackenburg R., Gottes Herrschaft und Reich. Eine biblisch-theologische Studie, Freiburg 1959.

Schumacher R., Aquila und Priscilla, „Theologie und Glaube” 1920, nr 12, s. 86-99. Stuhlmacher P. , Der Brief an die Römer (NTD $\left.{ }^{14}\right)$, Göttingen 1989.

Theobald M., Römerbrief. Kapitel 12-16 (SKK.NT 6/2), Stuttgart 2001. 
Thiessen W., Christen in Ephesus. Die historische und theologische Situation in vorpaulinischer und paulinischer Zeit und zur Zeit der Apostelgeschichte und der Pastoralbriefe (TANZ 12), Tübingen 1995.

Weiser A., Die Rolle der Frau in der urchristlichen Mission, w: G. Dautzenberg H. Merklein - K. Müller (red.), Die Frau im Urchristentum (QD 95), Freiburg in Breisgau 1983, s. 158-181.

Weiser A., VAku,laj-Pri,ska, Pri,skilla, w: H. Balz - G. Schneider (red.), w: EWNT I, 134n.

Wilckens U., Der Brief an die Römer. 3. Teilband. Röm 12 - 16 (EKK VI/3), Zürich - Einsiedeln - Köln - Neukirchen-Vluyn 1982.

Wolter M., »Reich Gottes« bei Lukas, „New Testament Studies” 1995, R. 41, s. 541-563.

Zimmermann H., Neutestamentliche Methodenlehre. Darstellung der historisch-kritischen Methode, neubearb. von K. Kliesch, Stuttgart ${ }^{7} 1982$.

Zmijewski J., Die Apostelgeschichte (RNT), Regensburg 1994.

Zmijewski J., Paulus - Knecht und Apostel Christi. Amt und Amtsträger in paulinischer Sicht, Stuttgart 1986.

\section{Fr Andrzej Najda: Spouses in the service of evangelization in the early Church}

The missionary activity of the early Church is mainly presented in Acts and Letters by St Paul. It was not only a domain of Apostles, missionaries and itinerant preachers, but also actively involved married couples. The couples worth mentioning are: Apostles and their spouses, married couples listed in Romans 16 and Philemon, and first of all Aquila and Priscilla who devoted their whole life to the service of the Gospel.

Key words: Marriage, Gospel, Apostle, the Early Church, Aquila, Priscilla. 